Nikolay Okhotin

Moscow

\title{
SOME NEW EPIGRAPHIC SOUTH ARABIAN - ETHIOPIAN ETYMOLOGIES
}

The purpose of the present note is to propose new etymological evidence for a few lexemes of Epigraphic South Arabian languages (usually Sabaic). Most of the relevant terms are more or less problematic from the point of view of textual interpretation so that at least some of the newly proposed cognates from Geez and Modern Ethiopian are potentially helpful for eliciting their meaning. All etymological comparisons are taken from the author's unpublished $\mathrm{Ph}$. D. thesis dealing primarily with the non-emphatic sibilants of ESA (Okhotin 1999). ${ }^{1}$ In each entry, the pertinent ESA root is followed by a concise examination of the relevant context(s) and the etymological discussion (introduced by \# and $\|$ respectively).

1. Sab. $\left\{s_{1} y=m\right.$ 'measure of weight' (SD 20).

\# The Sab. term is Hapax Legomenon in Ja 669/7 but the above meaning (already suggested by the editor and accepted, e. g., in Sima 2000:334) can be derived from the context: hknyw mr?hmw ... s slmn wms 3 dm s srfm wmdlthmy $\left\{s_{1} y m\right.$ 'they dedicated to their lord ... this statue and a silver inscription, the weight of both of them being one $\$ s y$ '. An alternative interpretation is proposed in Biella 375 ('verified, correct', with reference to Arb. Sāsin 'proper, fitting') though 'name of a weight' is also mentioned.

|| The etymological evidence for the translation 'measure of weight' comes from Tgr. ९əs (pl. ৎəsäs) 'a dry measure, measure (in general)' (LH 463), Tna. Səssi 'a wooden measure for cereals, about four kg.' (KTna. 1858).

2. Sab. $\left\{w s_{1}(=m)\right.$ 'plague, pestilence' (SD 23, BiELla 359), Min. $\uparrow s_{1}$ 'épidémie, peste' (LM 17).

\# Since the Sab. term is attested several times, its general meaning 'kind of disease' is rather transparent (v., e. g. Ja 645/10-13: hwfy ... grb $\{b d h w$... bn hww wiws ${ }_{1}$ wmwtt 'he saved ... the body of his servant ... from sickness, disease and plague').

|| In Müller 1962:83 Sws 1 was compared to Yem. Arb. Saws 'sprain, dislocation' (Piamenta 346), 'Verrenkung' (Behnstedt 878). For an alternative etymological interpretation v. Tgr. Saso 'fever, malaria' (LH 463), Tna. Saso id. (KTna. 1858). Other, less reliable parallels, are proposed in SED I No. 27.

\footnotetext{
${ }^{1}$ For the list of abbreviations used in this article see p. 400.
} 


\section{Sab. $h s_{3} s_{3}=m$ '(building material), mud brick (?), mortar, puddled clay (?)' (SD 72), 'material used in masonry' (Biella 192).}

\# The Sab. term is Hapax Legomenon but the meaning 'kind of building material' is relatively clear from the context: $m b r ? m h_{3} s_{3} m$ wibnm 'building work in $h$ and stones'.

|| To be compared to Arb. hisan 'sol dur recouvert de sable, où l'eau des pluies s'infiltre' (BK 1 429), Hrs. ḥōhi 'earth, land, soil, dust' (JH 57), Jib. háási 'soil' (JJ 118), Soq. hóhi (ḥoihe) 'terre' (LS 166) and Ethiopian terms for 'sand': Tna. hašäwa 'sand, strand, sandbank' (KTna. 212), Amh. ašäwa, ašawa 'sand' (K 1182), Cha. Eža Enm. Gyt. Muh. Sod. Sel. Wol. ašawa, End. ašawa, Msq. Gog. ašäwa 'sand' (LGur. 102).

\section{Sab. $k s_{1} d=m$ 'feebleness (of body)' (SD 79).}

\# According to SD, attested in Ja 670/9-11: whwPl bnhw ks $d m$ 'he made feebleness retreat from him'. An alternative interpretation proposed by the editor is to treat bnhw $k s_{1} d m$ as 'his son $k s_{1} d m$ '.

|| If the rendering of SD is accepted, note Amh. kässädä 'to become very thin, gaunt, emaciated' (K 1411).

\section{Sab. $s_{1} l \varphi=m$ 'mésure de capacité' (RMA 66).}

\# According to the editors, attested in RMA 15/6 ( $s_{1} l$ lim glglnm 'un sils de sésame'), with a reference to another text written on wood where sli tmrn 'une unité de mesure de dattes' is mentioned. This interpretation, accepted, e. g., in Sima 2001:286, has been placed to doubt in Stein 2003:180 (with an extensive discussion).

I| An etymological support for the translation 'kind of measure' is provided by Tgr. šəlləSo 'a measure, = 1.5 l.' (LH 206) and Tna. səlləSo 'small measure for grain that equals $1 / 3$ of an ənqa; small unmeasured amount of grain, a pinch of grain' (K Tna. 633). Amh. salle 'a large earthenware crock holding about two onsära-jugs' (K 441) can also be compared.

Sab. $s_{1} l$ 'kind of coin' (SD 125, Biella 336), attested in C 548/8 ( $\mathrm{hm} \mathrm{s}_{1}$ $2 s_{1} l \mathrm{l} m$ 'five $s l \uparrow$-coins $)^{2}$ is usually regarded as borrowed from Aramaic: Nab. slৎ, Plm. slৎ ‘certain coin' (HJ 788), Jud. silৎā ‘a weight and a coin' (Ja. 996), Syr. seli $\bar{a}$ 'moneta, drachma' (Brock. 477). One wonders whether the Arm. terms, otherwise without etymology, can also be compared to the above Ethiopian forms with a meaning shift 'kind of weight' > 'kind of coin'.

6. Sab. $s_{1} \uparrow s_{1} \uparrow(=m)$ 'summer season' (SD 122).

\# Attested several times together with other terms for agricultural seasons

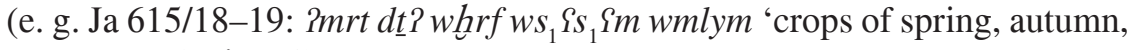
summer and winter').

\footnotetext{
${ }^{2}$ According to SiMA 2001:286, also in RMA 15/7.
} 
|| If Jamme's interpretation according to which «each term of the series indicates not the season itself, but the crops and fruits gathered during these periods of the year» (Jamme 1963:118) is correct, the Sab. term should probably be compared to Tgr. səSsə९a 'épeautre' (LH 194) and Tna. saisaia 'barley grown in the season following the small rains because it can subsist on the moisture in dew or fog or by irrigation and which is harvested before the big rainy season' (KTna. 764) rather than to Arb. $s$ \& $\$$ 'to pass away (months)' as suggested by Jamme (reproduced in Biella 340). The Ethiopian terms probably belong to a well-attested non-reduplicated prototype denoting a kind of cereal crop, represented by Akk. še $2 u$ 'barley, grain' (CAD Š2 345), Hbr. pB.

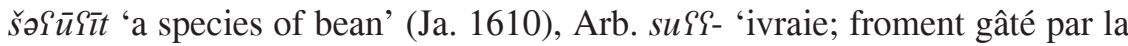
nielle' (BK 1 1090), Tgr. säSas 'oats' (LH 194) and Tna. sa9a؟ 'oats, kind of fodder; edible grass which grows mixed with barley' (KTna. 766).

\section{7. $s_{1} s t=n$ 'period, space of time' (SD 139, Biella 503).}

\# The Sab. term is Hapax Legomenon in R 3910/5 where it denotes the

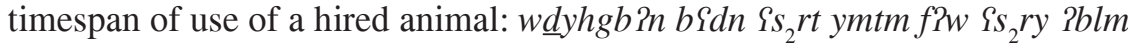
$f ? w$ twrm f?w birm flyhbn $s_{3} b h w s_{3}$ Stn $y s_{1} b$ ?n bilyhw «one who will return after ten days or twenty [days of use] a camel, a bull or a[ny other] beast, let him give its hiring price for the period he employed it».

|| While Ethiopian forms in -at (like Gez. sā $9 a t)$ are likely Arabisms, a few other terms, structurally different from Arb. sā $\bar{\uparrow} a t-$, may be suspected to

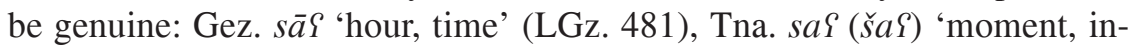
stant, time(s); time, hour' (KTna. 760), šastuy 'then, at that time, at this (that) moment, immediately' (ibid.), Har. sa 'time, at the time of' (LHar. 135). A similar dichotomy is observable in MSA: contrast Mhr. sā? 2 h 'hour, watch' (JM 353), Jib. sá9áh id. (JJ 232), Soq. sá9ah id. (LS 289) on the one

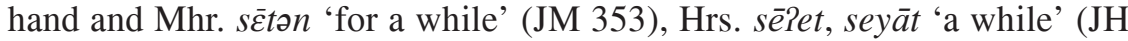
112), Jib. mən sáSté 'long ago' (JJ 232), Soq. le-sấYet 'à l'heure' (LS 289) on the other.

\section{Sab. $s_{1} w n$ 'towards' (SD 129), $s_{1} n n$ 'towards, in front of, next to, by' (ibid. 127), $s_{3} n n$ 'to, up to, next to, by' (ibid. 139).}

\# These three types of forms have been ususally treated as phonetic variants of one lexeme (Beeston 1984:58) but according to a recent study (Stein 2003:213-214) $s_{3} n n$ (with a late and phonologically innovative variant $s_{1} n n$ ) is to be kept apart from Middle Sabaic $s_{1} w n$.

|| The Sab. preposition is rightly compared to the widely used Eblaite preposition si-in 'to, for' in Fronzaroli 1979:13 and Archi 2002:8 (extensively discussed in the latter study where the meanings «allocutive 'to'», «allative, directive 'to'», «dative 'for, to'» and some others have been detected). Both are further to be connected with Cha. Enm. End. Gyt. Gog. sən, Eža sənn 'until, till, up to, as far as' (LGur. 549) as well as Jib. sín 'for, in a while, for 
a time' (JJ 268). Mhr. hən 'with, in the presence of, at' (JM 158) is also of interest but the correspondence Jib. $\widetilde{s} \sim$ Mhr. $h$ is atypical and the semantic difference is considerable.

\section{Abbreviations of Languages}

Akk. - Akkadian, Amh. - Amharic, Arb. - Arabic, Cha. - Chaha, End. — Endegeň, Enm. — Ennemor, Gez. — Ge ez, Gog. — Gogot, Gyt. Gyeto, Har. - Harari, Hbr. - Hebrew, Hbr. pB. - Post-Biblical Hebrew, Hrs. - Harsusi, Jib. - Jibbali, Jud. - Judaic Aramaic, Min. - Minaean, Mhr. - Mehri, Msq. — Masqan, Muh. - Muher, Nab. — Nabatean, Plm. Palmyrean, Sab. - Sabaic, Sel. — Selti, Sod. - Soddo, Soq. - Soqotri, Syr. — Syriac, Tgr. — Tigre, Tna. — Tigriňn̆a, Wol. — Wolane, Yem. Arb. Arabic dialect of Yemen.

\section{Abbreviations of Lexicographic Tools}

Behnstedt - P. Behnstedt. Die nordjemenitischen Dialekte. Teil 2: Glossar. Wiesbaden, 1992.

Biella - J. C. Biella. Dictionary of Old South Arabic. Sabaean Dialect. Chico, CA, 1982.

BK - A. de Biberstein-KAZIMIRSKi. Dictionnaire arabe-français. Vol. 1-2. Paris, 1860.

Brock - C. Brockelmann. Lexicon Syriacum. Halle, 1928.

CAD - The Assyrian Dictionary of the Oriental Institute of the University of Chicago. Chicago, 1956.

HJ - J. Hoftizzer, K. Jongeling. Dictionary of the North-West Semitic Inscriptions. Leiden — New York — Köln, 1995.

Ja.- M. Jastrow. A Dictionary of the Targumim, the Talmud Babli and Yerushalmi, and the Midrashic Literature. New York, 1996.

JH — T. M. Johnstone. Harsusi Lexicon. Oxford, 1977.

JJ — T. M. Johnstone. Jibbali Lexicon. Oxford, 1981.

JM - T. M. Johnstone. Mehri Lexicon. London, 1987.

K - T. L. Kane. Amharic-English Dictionary. Wiesbaden, 1990.

KTna - T. K. Kane. Tigrinya-English Dictionary. Springfield, 2000.

LGur - W. LesLau. Etymological Dictionary of Gurage (Ethiopic). Vol. IIII. Wiesbaden, 1979 [whenever quoted without number of volume, the $3^{\text {rd }}$ volume is referred to].

LGz - W. LesLau. Comparative Dictionary of $\mathrm{Ge}^{c} e z$ (Classical Ethiopic). Wiesbaden, 1987.

LH - E. LitTMann, M. HöFner. Wörterbuch der Tigre-Sprache. TigreDeutsch-English. Wiesbaden, 1956.

LHar - W. LeSLAu. Etymological Dictionary of Harari. Berkeley — Los Angeles, 1963. 
LM - M. ARbach. Le madabien: Lexique, Onomastique et Grammaire d'une langue de l'Arabie méridionale préislamique. T. I: Lexique madabien. Thèse de doctorat - Nouveau régime. Université de Provence Aix Marseille I. Centre d'Aix. Aix-en-Provence, 1993.

LS - W. Leslau. Lexique Soqotri (Sudarabique moderne) avec comparaisons et explications étymologiques. Paris, 1938.

Piamenta - M. Piamenta. Dictionary of Post-Classical Yemeni Arabic. Leiden - New York - København — Köln, 1990.

SD - A. F. L. Beeston, M. A. Ghul, W. W. Müller, J. Ryckmans. Sabaic Dictionary (English-French-Arabic). Louvain-la-Neuve, 1982.

SED - A. Militarev, L. Kogan. Semitic Etymological Dictionary. Vol. 1: Anatomy of Man and Animals. Münster, 2000.

\section{References}

Archi 2002 - A. ARCHI. «Prepositions at Ebla». Eblaitica 4: 1-21.

Beeston 1984 - A. F. L. BeEston. Sabaic Grammar. Manchester.

Fronzaroli 1979 - P. Fronzaroli. «Problemi di fonetica eblaita, 1». Studi Eblaiti 1: 65-89.

Jamme 1963 - A. Jamme. Sabaean Inscriptions from Mahram Bilqîs (Mârib). Baltimore.

Müller 1962 - W. W. MüLlER. Die Wurzeln mediae und tertiae $y / w$ im Altsüdarabischen: eine etymologische und lexikographische Studie. Diss. Tübingen.

Okhotin 1999 - N. Окнотім. Voiceless Non-Emphatic Sibilants of the Eigraphic South Arabian Languages: an Etymological Investigation. Unpublished $\mathrm{PhD}$. thesis, Russian State University for the Humanities.

Sima 2000 - A. Sima. Tiere, Pflanzen, Steine und Metalle in den altsüdarabischen Inschriften. Eine Lexikalische und realkundliche Untersuchung. Wiesbaden.

Sima 2001 - A. Sima. «Altsüdarabische Konditionalsätze». Orientalia 70: 283-312.

Stein 2003 - P. Stein, Untersuchungen zur Phonologie und Morphologie des Sabäischen. Rahden/Westf.

\section{SUMMARY}

Despite the enormous progress made in Sabaeology in recent decades, there still remain a significant number of Epigraphic South Arabian lexical items for which textual analysis has not yet provided any coherent interpretation. As far as such terms are concerned, Semitic etymology may sometimes provide precious clues for a better understanding of their meaning. The present article attempts to present a few newly proposed etymological connections between Ethiopian Semitic and Epigraphic South Arabian (mainly Sabaic). 